\title{
A musical matter of life and death: the morality of mortality and the coverage of Amy Winehouse's death in the UK press
}

Keywords: Death, Celebrity, Music, Morality, Media, Journalism, News Values

Biography: Paula Hearsum was a music journalist who is now a Senior Lecturer in popular music and journalism at the University of Brighton. Her published work also includes the biography, Manic Street Preachers: Design for Living (Virgin: 1996).

Email: p.hearsum@brighton.ac.uk

\begin{abstract}
Since the release of her debut album Frank in 2003, Amy Winehouse's life and death has been broadcast, mediated and much distorted through the lens of the press. Paul Gambaccini described her last years as being on "death watch" (BBC, 2011) and the singer's mother said that "we're watching her kill herself slowly. It's like watching a car crash." (in McVeigh: 2011) - a statement telling of the music industry, the media spectacle of death and of the way Winehouse had lived her life. As spectators we are all 'rubberneckers' of her car crash, and therefore it is fitting to examine the recurring narratives at play.
\end{abstract}

This article focuses on a sample of UK newspapers covering the period of Winehouse's death and funeral (July $23^{\text {rd }}$ - August $8^{\text {th }}$ 2011). The implicit 'news values' embedded in the content are contextualised through reference to earlier media coverage of Winehouse. This 'appetite' for a reader to consume death as the completion of a life 'story' is symptomatic of a context of how musicians' lives are constructed by the media in general. However, whilst some linguistic discourses examined are typical of the reporting of any celebrity death, this research also exposes discourses exclusively utilised for popular musicians whose deaths are framed as 'punishment' for reckless behaviour.

\section{Popular musicians and death}

In news value terms, coverage of popular musicians often emphasises three recurring themes, made famous by the Ian Dury and the Blockheads song, 'Sex \& Drugs \& Rock 'n Roll' (1976). When any of those elements result in an 'unexpected' death, the narrative as a whole ends up being greater than individual stories of the three types of excess, for instance, with Michael Hutchence (sex), Janis Joplin (drugs) and Kurt Cobain (whose rock'n roll lifestyle ended with a shotgun suicide). None of these tales, typically trotted out of rock n' roll excess, tend to discuss the underlying mental health issues (depression has been intimated in all three of those mentioned for instance). Therefore when the term 'unexpected' is used it is done so in its broadest sense, especially covering those who die prematurely rather than of 'natural causes'.

As broadcasters have moved into 24-hour cycles along with newspapers, magazines and their online equivalencies, there has been a parallel increase in the appetite for news consumption and our technological capabilities to access material. Special issues (in newspapers and magazines) produced after celebrity deaths are very particular artefacts for fans, epitomising the way the media remembers someone, as Kitch alludes:

“... magazines are the most savable of all journalistic media. When famous people die, magazine editors promote their coverage with labels such as 'commemorative edition'... and 'collectors' issue'. The cover of an issue remembering a famous person functions as a kind of tombstone and mourning object... a portrait to be preserved... Such content reveals editors' understanding of what Barbie Zelizer calls the materiality of collective memory." (Kitch, 2000:174) 
Consumption here is part of a grieving process and audience desire for an increasingly front-row insight into death is all too evident. By examining the press coverage of Winehouse's death (news, obituaries and columns), it is possible to discern to what extent journalism is reflective of, and plays a part in, shaping the views of the audiences it writes for and "by considering the ideological positioning of news coverage ... [one can] also gain an insight into broad societal views of behaviours in twenty-first-century western celebrity culture” (Hearsum \& Inglis, 2010: 239).

Within minutes of the BBC 'broadcasted' announcement during the late afternoon of July $23^{\text {rd }} 2011$, Wikipedia's 'Amy Winehouse' and '27 club' pages had been updated to include her death. In just over two hours The Telegraph's full obituary was online. Concurrently Twitter feeds 'narrowcasted' condolences from the famous intermingled with the morality-driven discussions from the public. It was estimated that over the weekend her death was announced, $10 \%$ of all Twitter usage (20 million users) were discussing her death (Verrico, 2011:2). During the following week 'special issues' of both OK! and NOW were published and, within a month, a biography updated and republished (Newkey-Burden: 2011). The deluge of media was far wider reaching in platforms than the traditional broadcast model coverage that followed the deaths of, for example, Presley (Gregory and Gregory 1980) or Lennon (Elliott 1999). However evolved the media technologies have become, Elliot's points remain useful to consider:

“The death of Lennon, like the deaths of Elvis Presley... has oftentimes been viewed through converging psychologies of denial and rationalization. The first dictates that death, and specifically the horror of death, be repressed in social practice and cultural remembering. The second transforms death into a spectacle, entertainment, banality. Relayed through new communication technologies, death is constructed and circulated as an object of consumption knowledge, and desire. In this commodified space, 'the pornography of death' (in Geoffrey Gorer's memorable phrase) rules supreme.” (Elliott, 1999: 148)

\section{The 27 Club}

For non-musical celebrities, an unexpected death (intentionally through suicide or unintentionally through reckless behaviour) would be a shocking end, but for several popular musicians, it is seen as the ultimate rite of passage into the ' 27 club'. Whilst there are a larger number of relatively young deaths in the profession (accidental deaths - plane, car, motorbike accidents etc), the table below highlights those known to have died at 27 either intentionally, through reckless behaviour or more suspicious circumstances:

\begin{tabular}{|l|l|l|}
\hline Musician & Cause of Death & Year \\
\hline Robert Johnson & Strychnine poisoning & 1938 \\
\hline Rudy Lewis & Drug overdose & 1964 \\
\hline Malcolm Hale & Carbon monoxide poisoning & 1968 \\
\hline Dickie Pride & Overdose of sleeping pills & 1969 \\
\hline Brian Jones & Drowned & 1969 \\
\hline Jimi Hendrix & Asphyxiation & 1970 \\
\hline Alan Wilson & Barbiturate overdose, possible suicide & 1970 \\
\hline Janis Joplin & Presumed heroin overdose & 1970 \\
\hline Jim Morrison & Presumed heart failure & 1971 \\
\hline $\begin{array}{l}\text { Ron "Pigpen" } \\
\text { McKernan }\end{array}$ & $\begin{array}{l}\text { Gastrointestinal hemorrhage associated } \\
\text { with alcoholism }\end{array}$ & 1973 \\
\hline Pete Ham & Suicide & 1975 \\
\hline Gary Thain & Drug overdose & 1975 \\
\hline Alexander Bashlachev & Suicide & 1988 \\
\hline Mia Zapata & Murdered & 1993 \\
\hline Kurt Cobain & Suicide & 1994 \\
\hline
\end{tabular}




\begin{tabular}{|l|l|l|}
\hline Kristen Pfaff & Overdose & 1994 \\
\hline Richey Edwards & Disappeared presumed dead & $\begin{array}{l}1995 \text { disappeared } \\
2008 \text { presumed dead }\end{array}$ \\
\hline Freaky Tah & Murdered & 1999 \\
\hline Sean Patrick McCabe & Asphyxiation & 2000 \\
\hline Jeremy Michael Ward & Heroin overdose & 2003 \\
\hline Bryan Ottoson & Prescription drug overdose & 2005 \\
\hline Valentín Elizalde & Murdered & 2006 \\
\hline Amy Winehouse & Alcohol poisoning & 2011 \\
\hline
\end{tabular}

As a journalistic shorthand this metaphor was used repeatedly in the sample, building on audience knowledge of those 'members' who pre-dated Winehouse (Brown: 2011, Clements: 2011, O’Hagan: 2011, Warren: 2011, Woo: 2011). Most commonly it was an opportunity to churn out a 'member' list, typified by Knight's clumsy bolt on:

\section{"That she joins the "Forever 27 club" of musical talents who died at the same age, and is now in the company of Janis Joplin, Jimi Hendrix, Jim Morrison and Kurt Cobain, is no comfort.” (Knight, 2011: 7)}

Meanwhile, McCormick also alluded to Kurt Cobain, citing Cobain’s mother’s famous admonition “...not to join that stupid club” (McCormick: 2011). The 'statistical spike' of 27 has not only been used by the press but also in books (Segalstad \& Hunter: 2008), as a play, a film and by academics (Bellis et al: 2007). As a mathematical probability, the ' 27 club' was probed by academic and media mathematician Matt Parker (2011) to consider both Winehouse specifically and the trend generally. Whilst there was most certainly a disproportionately higher number of musicians dying at 27 years old (around four times as many on average), Parker susggested it was "over-represented" in the media since "people make a huge fuss when it's 27 because it matches the 27 club” which "captures the public imagination” (Parker: 2011). Using Bellis’s (2007) research, he reworked the data set to test the health risk to musicians within their first years of fame and found that statistically these musicians had a $2.3 \%$ chance of dying compared to $0.3 \%$ for non-musicians of the same age. They also had a higher chance of dying than war zone soldiers of the same age in Afghanistan (1.9\%). As a profession, musicians may be deemed to be at a higher risk in terms of suicide specifically as research into the artistic professions has shown (Stack: 1996) they have become also increasingly likely as 'cultural producers' to have their deaths covered in the media (Fowler, 2005: 63). Deaths in other 'high risk' sports professions, such as motorcycling, have also been suggested for consideration through obituary analysis (Rojek, 2006: 689).

Parker's analysis chimes with the much-cited Russell Brand blog posting, which described the age as being "retrospectively romanticised" (Brand: 2011) and its mythologizing unhelpful (Freeman: 2011). The '27 club' phrase was used by all of the publications at some point during the period investigated, and typically as a hook, only a few used the opportunity to probe and question our use of the concept. Brown (2011) called it a 'presumed' spike, using Segalstad \& Hunter (2008) as evidence, although it is hardly an academically rigorous text. However, what was interesting was a reminder that not all musicians need follow the same path:

\footnotetext{
“...commentators continually referred to the 'grim inevitability' of Amy Winehouse's death... But social media reactions revelled a real level of public shock - for while her sad end may have been increasingly probable, it was never inevitable... Most rock stars seem to survive - and even recover - from their addictions than the tragic few who succumb. Against all the odds, Keith Richards is still with us.” (Brown, 2011: 17)
}

This point was reiterated by an article in The Telegraph (Gordon: 2011), which quoted Billy Bragg's tweet: "It's not age that Hendrix, Jones, Joplin, Morrison, Cobain \& Amy have in common - it's drug abuse, sadly" (Bragg: 2011). A news story is created on its packaging as much as its facts. 


\section{Multimedia epitaphs}

The Brand blog, used many times across several newspapers (including The Guardian and The Sun in full and cited by The Independent amongst others) demonstrates new ways in which the death of a famous person can reach the public. A blog offspring, Twitter, the microblog and social networking service, was at the forefront handling voices of condolences from other celebrities. Its utilisation demonstrates how journalistic practice has shifted from 'pull' to 'push' media. Once journalists fought to get quotes from another celebrity, now they draw on tweet feeds provided by celebrities themselves and intermingle them within their pieces or even collate them (Llewellyn Smith: 2011; AFP for The Independent: 2011 b; Chittenden \& Mansey, 2011: 7, Gordon: 2011). A mediated death now transmits quicker to technologically connected fans than to immediate family, suggesting a morally correct order in which a death is informed: "It somehow seems wrong that the world knew about Winehouse’s sad demise before her own father did” (Gordon: 2011).

Musical condolences, such as M.I.A’s unfinished demo '27' (M.I.A.: 2011) were identified with mixed reception, positively labelled as a 'tribute' by music press (ANON: NME.com: 2011) and described as in 'bad taste' by the Daily Mail (ANON: 2011). A similar morality was examined when Microsoft tweeted to encourage grievers to console themselves with commoditisation and "Remember Amy Winehouse by downloading the ground-breaking 'Back to Black' over at Zune” (ANON: Telegraph: 2011). The ethical debate signalled that fans had duly "honoured the singer not only with tributes and flowers, but by buying her music" (Topping: 2011a). Her album "Back to Black" rapidly "climbed back to the top of the albums chart, which is perhaps the most fitting tribute of all' (Martin \& Cooper, 2011, 11). There are, perhaps, right and wrong ways to show you care, but it seems inevitable that Winehouse will appear in the next Forbes dead earning celebrity list (Rose \& Pomerantz: 2010). According to industry insiders her death would "set the brand in stone for a decade-long income stream" (Fildes: 2011). Several commentators discussed the potential for posthumous music sales, particularly in a third album of unreleased material (Lachno: 2011; Topping: 2011 b), some also highlighting the inevitable forthcoming complications regarding who would receive the royalties (Hall, 2011: 17).

\section{Expert voices}

A recurring theme in the sample was the inclusion of citations from 'experts', positioned to cast their opinions. This is a well-known and typical journalistic tool. However, because the commentaries were released before toxicology reports had established the causes of Winehouse's death, the voices of the experts took on greater significance. The Times used three 'experts' on the same day in different sections. In his column in the main paper, the philosophic scientist, Raymond Tallis, suggested that she was not a 'passive victim' of her addictions (Tallis, 2011: 20). In the supplement's section, the 'experts' were the chief executive of a Suffolk residential rehabilitation unit and an 'independent addiction expert' $(O$ ' Connell: 2011), propounding a zero tolerance attitude towards drugs. In the news section, the expert was a 'friend of the singer' (Ralph, 2011: 11). The Daily Express (Warren: 2011) strung several experts together, including another musician Dave Dederer of The Presidents Of The United States Of America, presumed to have 'cultural proximity’with Winehouse (Galtung \& Ruge: 1965), and a psychologist:

\section{"Numerous studies have indicated that creative people are quite often more at risk of serious mental illness such as depression, addiction and bipolar disorder,” says psychologist Dr Ryan Janis, who has worked at an inpatient substance abuse recovery centre... (Warren: 2011)}

The juxtaposition of the voices suggests access to a 'truth', bolstered by words like 'research' and 'studies' suggesting factual evidence; Janis's position of authority is highlighted through reference to his areas of specialism, which are incidentally also highlighted on his personal website - 'addiction' and 'artists' (Janis: 2011). Meanwhile, The Times' Saturday Review ran a long piece by Winehouse's first manager, Nick Godwyn, with a frontpage caption reading 'The real Amy' and a standfirst of 'what she was really like', equating a personal view with fact by using the word 'real' (Godwyn: 2011, 1 \& 4). The toxicology results were 'two to four weeks away' from being announced but with unlimited space (online, in print and through social media) to speculate, everyone wanted "to be seen as an expert" (Greenslade in: McNair: 1999: 77), 
thereby saturating journalistic authority (Eason: 1986). This was most unpleasantly seen in the scurrilous rumour mongering used by the online gossip sites of $O K !$ which, on August 1st, put live a story that Winehouse was set to adopt before her death before - only to denounce it five hours later, presumably to drive web traffic. Milani’s (2007) remarks about the negotiable and changeable nature of expertise in the realm of education apply equally well to media commentary:

\section{“...these social positions become meaningful in discursive interaction as a way of corroborating and giving credibility to one's arguments. That is, they intersect with each other in the construction of the expert. Yet, these very social positions also become the subject of conflict and contestation, thus showing that the expert is a fluid and relational category which is constantly (re)negotiated in discourse.” (Milani, 2007: 116)}

The existence of multiple competing voices was especially apparent in the coverage of Winehouse's use of alcohol and drugs and judgements made in that regard. The key 'voice' here that all the sampled newspapers mentioned was that of her father, Mitch Winehouse; having been visible throughout her public career, unsurprising, he was sought for explanations following her death. He speculated that his daughter's death was caused not by drug but drink because, according to him, she had not been taking any drugs for the previous three years while alcohol had remained a concern (Topping, 2011: 15b). It is worth considering that this opinion was widely circulated inspite of an inconclusive post mortem and the well-known fact that parents do not always know the full details of their children's lives. Either way, there is a link to the next recurring theme about social views of death by reckless behaviour, revealing a pecking order of acceptability as to the types of addictions at play.

\section{Death through reckless behaviour}

Journalists who adhere to the NUJ code undertake ethical considerations in covering celebrities who have lived, and died, recklessly. Beyond being sensitive to the person and their loved ones, there is a wider consideration, known in the social sciences as the Werther Effect, whereby insensitive coverage might encourage someone else to follow the same path, specifically, suicide after the death of a famous person. The theory is based on Phillips's 1974 research linking suicides covered in the New York Times over a 20 year period compared to potential imitation by analysing suicide trends of the subsequent months and critiqued by several studies since (Wasserman: 1984; Frei et al: 2003) A year before her death, Winehouse herself was the case study for a group of academics who used Media Framing Analysis to examine the mediated impact of celebrity drug use upon youth behaviour; Shaw, Whitehead \& Giles (2010) concluded that she was not generally seen as a role model in light of her risky behaviour. It would certainly be worth running the same research again after her death to compare attitudes.

In keeping with the 'para-social' nature of interactions between fans and celebrities (Horton \& Wohl: 1956), much of the coverage following Winehouse's death played on a seemingly intimate and yet most often illusory relationship between subject and reader. Articles required people to be knowledgeable of her drug and alcohol dependencies and other facets of her life, promoting a 'pseudo-social' connection (Caughey, 1984: 33). Reference to Galtung \& Ruge’s (1965) set of 12 recurring 'news values' is pertinent here; it was precisely because of the 'predictability' and 'negativity' of Winehouse's behaviour and, of course, her status as an 'elite person' that she received so much coverage in the media, prompting people to feel that they 'knew' her.

Linguistic studies of newspaper lexicon have revealed that addicts and those with terminal illness both 'battle' their diseases. However, there is a hierarchy of sympathy for types of deaths: we feel sorrier for Jade Goody, for instance, than Winehouse. Although the word 'battle' was used in both sets of coverage, the morality implied was different. For Winehouse, the 'battle' with drink, drugs and/or personal problems was 'well-documented' and 'self-destructive' (Graham: 2011; McCormick : 2011; Topping: 2011a), suggesting that her condition was in part self-induced. Goody's 'battle' on the other hand was against cancer cells; she was fighting against an external force. 
Winehouse's relationship with her internal demons, whether relating to drink, drugs or relationships, framed both the obituaries and news coverage, frequently summed up through the use of descriptors such as 'troubled' (Lipman: 2011) and 'wild child' (Verrico: 2011). These qualities were once a selling point:

"Whether people know it or not they like their blues singers miserable. Maybe my audience can enjoy my music more if they think I'm destroying myself'” (Joplin in: Brown, 2011: 17)

This is an apposite point to remember another musician who died in media-salacious circumstances, Michael Hutchence, whose pertinent comments in $Q$ magazine were used again in his obituary:

"Rock'n'roll is the perfect scenario for people who need a lot of attention, who were ignored as kids. It's the most indulged, ridiculous situation. It used to be that as a rock star everyone was happy if you killed yourself.” (Hutchence: 1993)

\title{
Inevitability?
}

The sample revealed contrasting responses to Winehouse's death - surprise (relating to the news value of 'unexpectedness') and a feeling that her death was inevitable (relating to 'consonance'). The latter sentiment was reflected, for example, in The Times:

"It is a matter of record, not editorial pride, that the early death of the singer... was foretold in these very pages in 2008." (ANON: Times, 2011: 2)

A more vicious and sadly typical red top tabloid piece by The Mirror hailed that they too had predicted her death years before and that she had since become 'boring' (Hudson: 2009). But death cannot really be considered 'boring' as it fulfils many 'news values' in one swoop even if the death “...was not a surprise..." (Woo: 2011). Three broadsheets (Times and two Guardian pieces) questioned why Winehouse's death came as a shock despite years of media build up; Petridis (2011) articulates the paradox as follows:

\begin{abstract}
"Perhaps the most startling thing about Amy Winehouse's death was how startled people were by it. She was a drug addict whose crack use had, her father claimed, given her emphysema. She was a drinker who, by her own admission, “didn't know when to stop”. And, as she frequently pointed out, she “didn't give a fuck”.
\end{abstract}

It's the kind of story that usually only ends one way, and yet, the reaction to her death, my own included, was one of shocked disbelief." (Petridis, 2011: 7)

The first two days of the sample built on this theme of inevitability by repeatedly mentioning the last live appearance at Kalemegdan Park in Belgrade on June $18^{\text {th }}$ 2011. Before her death, tabloids had revelled that the singer's recent stint in a rehabilitation unit for her drinking was wasted - "So, that $£ 4,000$ on treatment was money well spent then Amy” (Moodie: 2011) - and the word 'shambolic' was used several times to describe her performance (Sherwin \& Sharp, 2011: 11).

As a cautionary tale, The Daily Mail posited, "Her fate serves as a terrible warning about the vicious cycle of drug-taking and alcohol” (Phillips: 2011), signifying a self-induced death before making a political leap to blame the 'imbecilic' Labour party for changing the opening hours of public houses. Typical 'blame seeking' hooks shifted from the artist herself to the industry who had allowed the last live performances to go ahead (Sherwin \& Sharp, 2011: 11), and to her ex-husband (ANON, Financial Times: 2011). McCormick (2011), whilst offering an alternative scenario, also suggested predictability in the last sentence:

“The terrible tragedy of Amy Winehouse is that none of this was inevitable... She could have come through it. Many addicts have recovered and gone on to live full and productive lives... But when you are a junkie, you really are one shot away from self-annihilation.”

(McCormick: 2011) 


\title{
Obituaries
}

The obituary is a fascinating journalistic artefact and much explored in studies relating to death and Journalism Studies as encapsulating societal views. Skilled obituary writers endeavour to do far more than simply create a mini-biography:

“...[They] pick over the expired human condition and deliver their posthumous review with a formidable exercise of authority. They inform, they enlighten, they entertain; they also have the capacity to offend and wound....There is a duty to present a complete account so that the cause of historical record is satisfied.” (Starck, 2007: 372)

In personal interviews conducted in 2010, several broadsheet obituary writers confirmed that they had already written Winehouse's obituary and, therefore, the speed at which they were put live following her death was unsurprising.

"At last we can wheel out those pre-written columns as we photograph her body being wheeled out of her house!” (Freeman: 2011)

Although they are highly formulaic in many respects, obituaries are often open to considering ethical debates and, even though they are not opinion pieces, the opening lines in particular sometimes frame a judgemental verdict. For Winehouse, the juxtaposition was always the astonishing musician versus a troubled personal life:

\section{"Despite being as famous for her private life as her music" (Sturges, 2011: 22) \\ “Amy Winehouse 's brilliant but troubled life has reached a dismal conclusion.” (Hunter-Tilney: 2011: 13)}

\begin{abstract}
Amy Winehouse... ticked all the right boxes for a self-destructive wild child of pop, having bags of 'attitude', a drink and drugs problem and a no-good man” (ANON: Daily Telegraph, 2011)
\end{abstract}

Obituaries may also mention who the deceased is survived by, typically a partner and children, or for a young person, their parents. So whilst the latter is true in the case of Winehouse, unusually, the Telegraph obituary mentioned that she was survived by 'her former husband' (ANON: 2011) and The Independent added the details: "married 2007 Blake Fielder-Civil (divorced 2009)" (Sturges: 2011: 23). Neither source mentioned Reg Traviss, her actual partner at the time of her death - possibly because the pieces were pre-written and hurriedly re-edited or, alternatively, because the editors conservatively recognize formal partnerships even after they have been legally dissolved.

\section{A space for fans}

Post-death coverage of a celebrity commonly also includes interviews with fans. Following the announcement of death, fans typically congregate in spaces that are particularly associated with the deceased, as demonstrated in the cases of Presley, Lennon and Cobain. Winehouse's fans gathered and laid tributes at the edge of a cordoned off area in Camden Square in North London and also outside Golders Green Crematorium, where her funeral was held. Such gatherings are sometimes interpreted as semi-religious phenomena that help people to express and understand grief. In discussing Presley fans' tours of Gracelands, Doss suggests that:

"People build shrines and make pilgrimages for religious reasons, because of deeply felt needs for meaning and enlightenment, in hopes of salvation or expectations of spiritual satisfaction, and as tributes to special, sacred figures, things, or places.” (Doss, 2005: 75) 
Winehouse's fans gathered not only to visit the places she lived and died as an act of 'paying respect' (Kingsley, 2011: 3) but also to be together with likeminded people in a time of mourning; this was clarified by fans' comments quoted in the sample. Winehouse's mother validated the gatherings in a statement to the crowd:

\footnotetext{
"We are so glad you are here. I know a lot of you. We have been together for five or six years. You people in the street I can't tell you what it means to us. It has made (her death) a lot easier for us." (Foster: 2011)
}

Certain sources, however, chose to represent additional motivations behind individuals' actions. Catching a moment of self-reflection, The Independent, in presenting the voice of a visitor to Winehouse's home after her death, turned judgement on its readers:

“'I am not a fan - I'm more of a cultural-sociological tourist,' said Jennifer White, 31, visiting from Brighton. 'I am here for the spectacle of it all. It's obscene but it's what we do, isn't it?’” (Sharp \& Binns: 2011: 11)

Kear \& Steinberg's classic analysis of the public mourning of Princess Diana includes a chapter by Greenhalgh discussing the complex symbolic meaning of the 15, 000 tons of flowers left across royal sites (Greenhalgh, 1999: 42). Seen as being cathartic expressions of communal and personal sentiment and a 'transient' way of mourning (1999: 55), the flowers offered a visually stunning display ideally suited to media reportage. Since then, it has become standard practice to include images of gathered fans and amassed tributes. For musicians in particular, tributes sometimes include less formal gifts and, in Winehouse's case, many articles mentioned and photographed bottles of alcohol left (perhaps ironically) between the flowers (nme.com: 2011; ANON: Telegraph, 2011) and 'shrines' (Cairns: 2011).

Codes of behaviour at mourning sites (whether homes or graves) differ markedly according to the character of the subject and the values of the fans. For instance, it is deemed not unsuitable to smoke or leave marijuana as a 'gift' at Jim Morrison's grave at Père Lachaise in Paris, even respectful (Margry, 2008: 151); this contrasts dramatically with behaviour at sites for establishment figures such as Princess Diana. In Winehouse's case, the images of the gathered fans and the nature of the tributes conveyed mixed messages depending on readership. Where there was no opinion given in the left field press and music papers, this was not so of the more conservative mid-market tabloids such as the Daily Mail (Harris: 2011) who declared a cause of death before the results were known, casting judgement on singer and fans alike:

“...it didn't take long before the makeshift shrine began to lose what little dignity could remain when a carpet of flowers is swollen by empty vodka bottles and beer cans, poorly spelled messages and attention-seeking visitors.

The vodka bottles were presumably left as a hallmark of Miss Winehouse's drunken lifestyle, placed at her 'shrine' in the way that a mourner might leave a child's toy at their graveside.

But yesterday, as toxicology tests were being carried out to confirm whether she died in a drink and drug binge, they took on a macabre symbolism.

For whatever the final results of the post-mortem examination, there is no doubt that the Grammy Award-winner drank herself into oblivion.” (Harris: 2011)

There would be value in examining the blogs of online publications as a litmus test on general public opinion. Many forums were attached to news articles giving space to discussions from readers which continued the same debates and moralities of life and death (Daily Mail, Guardian, The Sun and BBC sites). 


\section{Redemption for women in death}

In discussing the mediated death of Jade Goody, Walter (2010) draws on Kitch's consideration of the coverage of 9/11 and redemption in death. The death of a 'tortured' artist opens up more journalistic analogies. Both in life and death Winehouse was likened to another female musician known for her drug use, Billie Holliday:

"When an addict self-annihilates, stalked by paparazzi, it is easy to imagine the story belongs to us all. We had a stake in Amy Winehouse, you might believe; her fall, and the redemption that will never come now, had a universal meaning. But it didn't... Creative addicts particularly females creative addicts - are always clutched to the cold global breast, even as the corpse is carried out." (Gold, 2011: 25)

While the sample reveals a general consensus that Winehouse was inevitably going to die young, there was no such consensus regarding her redemption, although reference to her Jewish funeral offered a potentially redemptive dimension. What was evident was the focus on her musical legacy as a lasting redemptive gift, opening the gates for performers such as Adele and Duffy: "Amy Winehouse shaped the current music scene even as she absented herself from it” (Walker, 2011: 3). Redemption through others was also suggested a few weeks before her death when Tony Bennett (whose 'Body and Soul' duet with Winehouse was released posthumously as a charity single) was reported to have said:

"I'm worried about her and I'm praying for her," he said. 'She'd help everyone by sobering up and cleaning up her spirituality'.” (O’Sullivan: 2011)

Just as Jade Goody's death prompted an increase in the number of women going for cervical cancer tests (Metcalfe, Price \& Powell: 2011), Winehouse's death has encouraged increased awareness of alcohol and drug dependency issues - which can, in itself, be interpreted as a form of redemption. For instance, The Independent interviewed an addiction therapist, confirming an increase in the number of clients seeking support: "the death of a public figure is bringing it home to many that the addiction is an illness that can kill and needs to be dealt with" (Sharp, Sherwin \& Rawlinson: 2011: 11). Plans to establish an Amy Winehouse Foundation also suggest that good things may yet come out of her death, but it is unlikely that her 'demons' can be exorcised from public remembrance, having been so extensively and vividly documented:

"The photographic documentation of her demons appear even more ghoulish now. Winehouse with her trademark black eyelines woops smeared across her face, her pink ballerinas caked in blood and dirt and her then husband Blake Fielder-Civil's face covered in scratches in $2007 . .$. her death, like her life, has been lit by the glare of dozens of camera flashes” (Topping: 2011: 15b)

Winehouse's relationship with Fielder-Civil was sometimes pinpointed as being to 'blame’ (Verrico, 2011: 1) and there were analogies to an earlier turbulent and drug-fuelled celebrity relationship - that between Sid Vicious and Nancy Spungen. The couple's relationship was described as “the full Sid'n'Nancy trip” (Verrico, 2011: 1) or “a Sid- and-Nancy-style theatre of destruction” (Molony \& Reihill: 2011; see also Telegraph: 2011). Very few commentators were insightful or daring enough to suggest that salvation could only be sought if the media themselves self-reflected on the part they played. Orr (2011) was one of those who did:

“... the media itself is a particularly dangerous and irresponsible enabler of celebrity addicts. It does not tell people that there will be no more attention until the problem is addressed. It tells people the very opposite." (Orr 2011: 9)

Winehouse's funeral was covered in almost as much detail as her death. Because it followed the Jewish tradition of taking place within a few days of death, there was a pronounced sense of 'continuity' with previous coverage - this being another of Galtung \& Ruge's (1965) news values. The funeral was restricted to family, but Sun reporter Gordon Smart was invited and made much of it in his piece: 
"I can vouch for the authenticity of every word... I was invited to the funeral by her trusted manager Raye Cosbert on behalf of the family yesterday morning. I need to be absolutely unequivocal about why I am writing about what happened inside. It is not a mawkish, claiming-of-credit exercise, boasting about being the only journalist there.” (Smart: 2011)

This was immediately spun negatively by The Times (even though both are owned by News International):

"The service was meant to be for friends and family only, but one tabloid reporter managed to secure an invitation: in the world of celebrity mourning, private is a relative term.” (Low \& Ralph: 2011: 4)

Later in the same article, the authors make the cutting comment that "only the most dedicated of the media" had gone to Edgwarebury service, compared to the media-fest of the Golders Green crematorium (Low \& Ralph: 2011: 4).

The Jewish Chronicle's observance of the media's reporting of Winehouse's death and funeral arrangements paid attention to the misinformation of many journalists of Jewish custom. Alderman (2011) noted NME.com's misunderstanding of the timing of sitting shiva, The Times' labelling of the service as 'orthodox' (which a cremation is not deemed to be) and the Daily Mirror's website proclamation that she would have to have her tattoos 'cut off' (later removed from the website) when being buried 'whole'.

\section{Conclusion}

'I died 100 times' (Winehouse: Back to Black, 2007)

Revisiting lyrics is a journalistic mechanism used to evidence death premonitions. Gill (2011) suggested the 'authenticity' of her addictions was articulated lyrically (Gill: 2011: 14). As the fortnight drew to an end, so came our compassion fatigue and the stories petered out. They will have been replaced several times over with the results of the toxicology reports, the release of the posthumous material, her birthday, the anniversary of her death, the opening of the rehabilitation unit in her name - that, after all, is how news values work.

While this article may seem to offer a disheartening critique of the coverage following Winehouse's death, a glimmer of possibility remains that some may take heed of Orr's journalistic call for change:

"The need for clear and firm guidelines on the reporting of addictive mental illness, not dissimilar to those already available as a guide to the reporting of suicide (actual and attempted), need to be formulated and adhered to. Currently, the way the press covers addicts is barbaric, like bear-baiting or throwing a witch in a pond to see if she will sink or swim. It has to stop.... The current trend towards 'open season' on high-profile substance abusers is cruel, inhumane, shameful and an appallingly bad example to a society that needs, quite urgently, to understand addiction, and how to combat it” (Orr: 2011, 9)

If journalists can isolate the underlying issues that dictate paths of self-destruction, then there is an opportunity to educate. However, an important observation is raised by Gold - herself a recovering alcoholic, formerly treated in The Priory like Winehouse -, namely that we, the readers, also need to question our own desires to be spectators:

"Why do we give so much energy to the thrilling pantomime of an alcoholic dying in the public eye, and so little to understanding the illness that too her there?” (Gold, 2011: 25)

In discussing the Twitter coverage of Winehouse's death, Gordon (2011) equates its usage to "the online equivalent of slowing down to look at a traffic accident. Rubber-necking” (Gordon: 2011). In terms of fighting for attention, Winehouse's death occurred just as another story had broken in Norway: the same weekend that Winehouse died, Anders Breivik massacred just under 100 people. The broadcasted news and 
print counterparts ran both stories in detail although attitudes clearly differed as to which story deserved more space and consideration. Death, however, isn't a competition... It's a shame the media and society makes it one. 


\section{Bibliography}

Please note that many of the newspaper and magazine article are available online.

AFP (a). 2011. Singer Winehouse joins tragic '27 Club'. Independent. July 23 2011.

AFP (b). 2011. 'Stars mourn Winehouse in Twitter Tributes’. Independent. July $23^{\text {rd }} 2011$.

Alderman, G. 2011. 'Death that exposed ignorance’. Jewish Chronicle. Aug 8 2011.

ANON. 2011. 'Fans hold street party outside Amy Winehouse's home after her funeral’ July $27^{\text {th }} 2011$.

NME.com.

ANON. 2011. 'Too soon, too soon! M.I.A releases unfinished demo called '27' in tribute to Amy Winehouse'. Mailonline. July $25^{\text {th }} 2011$.

ANON: 2011. 'Amy Winehouse dies aged 27’. Financial Times. July 24 2011.

ANON: 2011. ‘Amy Winehouse: Obituary’. Telegraph. July $24^{\text {th }} 2011$.

ANON: 2011. 'Amy Winehouse: Wild child of pop whose smoky, sensual talents were overwhelmed in a charge to self-destruction'. Telegraph. July $25^{\text {th }} 2011$.

ANON: 2011. 'The songs remain: the sad death of Amy Winehouse does not diminish her talent'. Times. July $25^{\text {th }}$ 2011. p2.

ANON. 2011. 'Amy Winehouse death: family to hold private funeral for the singer'. Telegraph. Aug $8^{\text {th }} 2011$.

ANON. 2011. 'Microsoft apologises for 'cynical’ Amy Winehouse tweet'. Telegraph. July $25^{\text {th }} 2011$.

ANON. 2011. Hear MIA's Amy Winehouse tribute song on NME.COM'. NME.com. July $24^{\text {th }} 2011$.

Bellis, M., Hennell, T., Lushey, C., Hughes, K., Tocque, K., \& Ashton, J. 2007. ‘Elvis to Eminem: quantifying the price of fame through early mortality of European and North American rock and pop stars'. Journal of Epidemiology and Community Health. Vol. 61. Issue. 10. pp896-901

Bragg, B. 2011 @billybragg Billy Bragg \#27club. July 23 ${ }^{\text {rd }}$ 2011. Available at: http://twitter.com/\#\%21/billybragg.

Brand, R. 2011. 'For Amy’. July 24 ${ }^{\text {th }}$ 2011. Available at: http://www.russellbrand.tv/.

Brown, H. 2011. ‘ Amy Winehouse: Another burnt out case at 27’. Telegraph. July 25 2011.

Cairns, D. 2011. 'The nervous waif who became a powerhouse'. Sunday Times. July $24^{\text {th }} 2011$.

Caughey, J. 1984. Imaginary Social Worlds: A Cultural Approach. Lincoln: University of Nebraska Press.

Chittenden, M \& Mansey, K. 2011. 'The first British singer to win five Grammys'. Sunday Times. July $24^{\text {th }}$ 2011.

Clements, P. ‘Amy Winehouse joins the ‘Forever 27’ Club’. Telegraph. July 24 2011.

Doss, E. 2005. 'Elvis Forever' in: Jones, S \& Jensen, J (Eds). 2005. Afterlife as Afterimage: Understanding Posthumous Fame. New York: Peter Lang. 
Eason, D. 1986. 'On journalistic authority: the Janet Cooke scandal'. Critical Studies in Mass

Communication. Vol. 3. No 4. pp429-47.

Elliott, A. 1999. The Mourning of John Lennon. California: University of California Press.

Fildes, N. 2011. 'Death boosts a dwindling bank balance'. Times. July 25 2011.

Foster, A. 2011. 'Winehouse parents in tears as they read tributes at her home' Evening Standard. July $25^{\text {th }}$ 2011.

Fowler, B. 2005. 'Collective Memory and Forgetting: Components for a study of Obituaries. Theory, Culture \& Society. No. 22. Vol 53. pp53-72.

Freeman, H. 2011. ‘Amy Winehouse’s death was badly reported'. Guardian. July $26^{\text {th }} 2011$.

Frei. A., Schenker. T., Finzen. A., \& Dittmann. V et al: 2003. 'The Werther Effect and Assisted Suicide'. Suicide and Life-Threatening Behavior. Vol. 33. No. 2. pp. 192-200.

Gambaccini, P. 2011. 'Amy Winehouse: we’ve lost 20 years of good records’. BBC News 24. July $23^{\text {rd }} 2011$.

Galtung, J., \& Ruge, M. 1965. 'The Structure of Foreign News: The Presentation of the Congo, Cuba and Cyprus Crises in Four Norwegian Newspapers’. Journal of Peace Research March 1965. 2/1. pp. 64-91.

Gill. A. 2011. 'Music and drugs: It’s a hard habit to break'. Independent. July 29 ${ }^{\text {th }} 2011$. pp14-15.

Godwyn, N. 2011. 'Amy Wienhouse; Amy said, 'I want to sing a bit... be a waitress'. Saturday Times Review. July $20^{\text {th }}$ 2011. pp1-5.

Gold, T. 2011. 'Amy is dead, a myth is born'. Guardian. July 25 2011.

Gordon, B. When grief goes public'. Telegraph. July $26^{\text {th }} 2011$.

Graham, D. 2011. 'Amy Winehouse documentaries and tributes flood television schedules. Metro. July $28^{\text {th }}$ 2011.

Greenhalgh, S. 1999. 'Our Lady of Flowers: The ambiguous politics of Diana’s floral revolution' in: Kear, A. and D.L. Steinberg (eds). 1999. Mourning Diana: Nation, Culture and the Performance of Grief. London: Routledge. pp40-59.

Gregory, N \& Gregory, J. 1980. When Elvis Died: Media Overload \& the Origins of the Elvis Cult. New York: Pharos Books.

Hall, R. 2011. 'Winehouse’s back catalogue takes over the top 40’. Independent. July 30 2011.

Harris, P. 2011. 'It didn't take long for Amy's shrine to lose its dignity amid a sea of vodka bottles, beer cans and a stream of attention-seekers'. Mailonline. July $26^{\text {th }} 2011$.

Hearsum, P. \& Inglis, I. 2010. 'When two worlds collide'. Journal of Celebrity Studies. Vol 1. No. 2. pp239 241.

Horton, D., \& Wohl, R. 1956. 'Mass communication and para-social interaction'. Psychiatry. Vol. 19. pp215-229.

Hudson, P. 2009. 'Wasted Amy Winehouse is just a waste of space'. Mirror. June $11^{\text {th }} 2009$. 
Hunter-Tilney, L. ‘A troubled life with a dismal conclusion'. Financial Times. July $25^{\text {th }}$ 2011. p11.

Hutchence, M. 1993. Interview in Q, cited in: Perrone, P. 1997, 'Obituary: Michael Hutchence’. Independent. Nov 24th 1997.

Janis, R. 2011. Personal website: http://www.drryanjanis.com/specialties.html.

Kear, A. and D.L. Steinberg (eds). 1999. Mourning Diana: Nation, Culture and the Performance of Grief. London: Routledge.

Kingsley, P. 2011. 'Amy Winehouse fans pay their respects'. Guardian. July $24^{\text {th }} 2011$. p3.

Kitch, C. 2000. 'A news of feeling as well as fact: Mourning and memorial in American newsmagazines'. Journalism. Vol. 1. No. 2. pp. 171-95.

Knight, I. 2011. 'She sang of a life times’s worth of loss and pain’. Sunday Times. July $24^{\text {th }} 2011$.

Lachno, J. 'Amy Winehouse's third album to cover marriage break-up and addiction problems'. Telegraph. Aug $1^{\text {st }} 2011$.

Llewellyn Smith, C. 2011. 'Twitter reaction to Amy Winehouse death’. Guardian. July 23 2011.

Lipman, J. 2011. ‘Amy Winehouse found dead at age 27’. Jewish Chronicle. July 23 2011.

Low, V \& Ralph, A. 2011. 'Celebration of an 'angel' played out in public glare at funeral'. Times. July $27^{\text {th }}$ 2011. pp4-5.

McCormick, N. 2011. 'Amy Winehouse had talent to burn. Instead, it burned her'. Telegraph. July $23^{\text {rd }} 2011$.

McVeigh, T. 2011. 'She was a sweet, tiny thing with this huge great voice'. Guardian, July $23^{\text {rd }} 2011$.

Mackay, E. 2011. 'Amy Winehouse: 1983-2011'. NME. July 30 2011. pp6-9

Margry, P (Ed). 2008. Shrines and Pilgrimage in the Modern World. New Itineraries into the Sacred. Amsterdam. Amsterdam University Press. pp. 145-173.

Martin, D \& Cooper, D. 2011. 'After the shock, the world remembers Amy’. NME. Aug $6^{\text {th }}$ 2011. pp.10-11.

Molony, J. \& Reihill, C. 2011. 'Amy and the long goodbye’. Irish Independent. July 31 2011.

McNair, B. 1999. Journalism and Democracy: An Evaluation of the Political Public Sphere. London: Routledge.

Metcalfe, D; Price, C \& Powell, J. 2011. 'Media coverage and public reaction to a celebrity cancer diagnosis’. Journal of Public Health. Vol. 33. No.1 pp80-85.

Milani, T. 2007. 'Voices of authority in conflict: The making of the expert in a language debate in Sweden'. Linguistics and Education Vol. 18. pp.99-120.

Moodie, C. 2007. 'Amy and husband could end up dead like Sid and Nancy, warns her father-in-law'. Mailonline. Aug $28^{\text {th }} 2007$.

Moodie, C. 2011. 'Amy Winehouse cancels gigs after shambolic comeback gig in Serbia'. Mirror. June $20^{\text {th }}$ 2011. 
Moran, C.' I can’t stop watching Amy because I can’t work out exactly how I feel about her dying'. Times Magazine. August $6^{\text {th }} 2011$.

Newkey-Burden, C. 2011. Amy Winehouse: The Biography 1983 -2011. London: John-Blake Publishing. NME. 2011. ‘Amy Winehouse’ July 30 ${ }^{\text {th }}$ 2011. pp.6-15.

NUJ code of conduct. Available here: http://www.nuj.org.uk/innerPagenuj.html?docid=174.

O’ Connell, A. 2011. 'Is it time to just say no again? Times (T2). July 26 2011.

O’Hagan, S. 2011. 'Amy Winehouse joins the list of rock stars ravaged by drugs’. Guardian. July $23^{\text {rd }} 2011$.

O’Sullivan. 20011. 'Amy Winehouse is in my prayers, says Tony Bennett'. Guardian. July $4^{\text {th }} 2011$.

Orr, D. 2011. ‘Celebrity and self-consciousness: a recipe for addiction’. Guardian: G2. July $28^{\text {th }} 2011$.

Parker, M. 2011. Interviewed on 'More or Less'. Radio 4. Aug $8^{\text {th }}$ 2011. Available at:

http://www.bbc.co.uk/programmes/b006qshd.

Petridis, A. 2011. ' A losing game’. Guardian: G2. July 25 th 2011. pp.7-9.

Phillips, M. 2011. 'A life lost, a talent squandered, and a celebrity culture that worships self-destruction'. Daily Mail. July $25^{\text {th }} 2011$.

Phillips, R. ‘Amy Winehouse’s dad has message for fan with baby’. Sun. July $26^{\text {th }} 2011$.

Ralph, A. 'Cause of death still unknown but singer will be buried today'. Times. July $26^{\text {th }} 2011$.

Rojek, C. 2006. 'Sports Celebrity and the Civilizing Process'. Sport in Society. Vol 9. No. 4. pp674-690.

Rose, L, \& Pomerantz, D (eds). 2010. ‘The Top-Earning Dead Celebrities'. Available at: http://www.forbes.com/2010/10/22/top-earning-dead-celebrities-business-entertainment-dead-celebs10_land.html.

Segalstad, E \& Hunter, J. 2008. The 27s: The Greatest Myth of Rock \& Roll. Berkeley Lake: Samadhi Creations.

Sharp, R \& Binns, K. 2011. 'Tearful fans pay homage to Winehouse’. Independent. July 25 2011.

Sharp, R. Sherwin, A. \& Rawlinson, K. 'Autopsy fails to identify singer's cause of death'. Independent. July $26^{\text {th }}$ 2011. p. 11.

Shaw, R. Whitehead, C. \& Giles, D. 2010. 'Crack down on the celebrity junkies: Does media coverage of celebrity drug use pose a risk to young people?’ Health, Risk \& Society. Vol. 12: No. 6. pp575-589.

Sherwin, A. \& Sharp, R. 2011. 'Recriminations fly over decision to let Winehouse make final tour'. Independent. July $26^{\text {th }}$ 2011. p11.

Smart, G. 2011. 'Nearest and dearest numbed by loss of Amy Winehouse'. Sun. July $27^{\text {th }} 2011$.

Sullivan, C. 'Amy Winehouse is in my prayers, says Tony Bennett'. Guardian. July $4^{\text {th }} 2011$. 
Stack, S. 1996. 'Gender and suicide risk among artists: A multivariate analysis'. Suicide \& Life Threatening Behavior. Vol. 26. No. 4. pp374-9.

Starck, N. 2007. 'Revelation, Intrusion, and Questions of Taste: The ethical challenge for obituary editors'. Journalism Practice. Vol 1. No. 3. pp.372-382.

Sturges. F. 2011. 'Amy Winehouse: Singer who won the hearts of millions but was unable to overcome her dependency on drink and drugs'. Independent. July 25th 2011. pp.22-23.

Tallis, R. 2011. 'This sublime talent did not die of a disease'. Times. July $26^{\text {th }} 2011$.

Topping, A. 2011. (a). ‘Amy Winehouse's family pay tributes as album sales surge’. Guardian. July $24^{\text {th }}$ 2011.

Topping, A. 2011. (b). 'How the light went out for the good-time girl who did not want fame'. Guardian. July $28^{\text {th }} 2011$.

Verrico, L. 2011. ‘One Demon Too Many’. The Sunday Times: News Review. July 31 2011.

Walker, H. 2011. 'The leader of the pack'. Independent: Viewspaper. July $26^{\text {th }} 2011$. pp2-3.

Walter, T. 2010. 'Jade and the journalists: Media coverage of a young British celebrity dying of cancer'. Social Science \& Medicine. Vol 71. Issue 5. pp 853-860.

Warren, J, 2011. 'Doomed to die young'. Daily Express. July 25 2011.

Wasserman, I. 2984. 'Imitation and suicide: A reexamination of the Werther Effect'. American Sociological Review. Vol 49. No. 3. pp. 427-436.

Woo, E. 2011. Amy Winehouse dies at 27; iconoclastic British singer-songwriter. Los Angeles Times. July $24^{\text {th }} 2011$. 